\title{
KEPEMIMPINAN SITUASIONAL DAN KOMUNIKASI INTERPERSONAL DALAM MENINGKATKAN KOMITMEN GURU
}

\author{
Heni Hikmayani Fauzia ${ }^{1}$, Bibin Rubini ${ }^{2}$, Widodo Sunaryo ${ }^{2}$ \\ ${ }^{1}$ Guru SMA Al Bayan Cibadak, Sukabumi, Jawa Barat \\ ${ }^{2}$ Program Pascasarjana Universitas Pakuan, \\ Email: pasca@unpak.ac.id
}

\begin{abstract}
This research outlines the correlation between the headmaster's situational leadership and interpersonal communication on organizational commitment. The research was conducted in private islamic school in the Sagaranten Sukabumi, West Java,Indonesia. Survey and data were conducted by applying regression and correlation analysis to test the correlation of two independent variables of situational leadership and interpersonal communication to one independent variable of organizational commitment. Tested on the level of confident of 0,05 and 0,01 to 109 teachers by using proportional random sampling, the result reveals that situational leadership can improve organizational commitment up to 18,75\%, interpersonal communication contributes $10,47 \%$. It can be inferred that organizational commitment can be enhanced through situational leadership and interpersonal communication.
\end{abstract}

\section{Keywords : Situasional Leadership, Interpersonal Communication, Organizational Commitment}

\begin{abstract}
ABSTRAK
Penelitian bertujuan untuk mengetahui hubungan antara kepemimpinan situasional dan komunikasi interpersonal dengan komitmen terhadap organisasi. Penelitian dilaksanakan di Sekolah MTS swasta yang berada di wilayah Kelompok Kerja Madrasah (KKM) MtsN Sagaranten Kabupaten Sukabumi, Jawa Barat Indonesia. Analisis survei dan data menggunakan regresi dan analisis korelasi untuk menilai hubungan dua variabel bebas yaitu kepemimpinan situasional dan komunikasi interpersonal terhadap satu variabel terikat yaitu komitmen terhadap organisasi. Tingkat signifikan menggunakan taraf signifikansi 0,05 dan 0,01 terhadap 109 guru dengan menggunakan proporsional random sampling, hasil penelitian menunjukkan bahwa komitmen organisasi dapat meningkat 18,75\% melalui kepemimpinan situasional dan komunikasi interpersonal berkontribusi sebesar 10,47\% Maka disimpulkan bahwa komitmen terhadap organisasi dapat ditingkatkan melalui kepemimpinan situasional dan komunikasi interpersonal.
\end{abstract}

Kata kunci: Kepemimpinan Situasional, Komunikasi Interpersonal dan Komitmen terhadap Organisasi.

\section{PENDAHULUAN}

Sekolah sebagai tempat terpenting bagi siswa selain di rumah, perlu dibuat sebaik dan senyaman mungkin baik itu dari proses pembelajaran ataupun suasana belajarnya. Sekolah adalah tempat siswa belajar dan menjadi seorang manusia yang cerdas dan berilmu tinggi serta berkarakter. Guru berperan penting dalam mewujudkan semua cita cita dan peran siswa di masa datang. Tanpa guru tidak mungkin akan tercipta sosok manusia cerdas, pembelajar 
dan berkarakter serta bermoral baik yang diperlukan untuk membangun bangsa dan negara Indonesia.

Guru adalah sosok terpenting dalam kegiatan proses pembelajaran. Untuk menjadi guru yang baik tidak mudah, banyak syarat yang harus dipenuhi dan beragam kompetensi harus tercapai. Dalam bekerja seorang guru harus mempunyai komitmen terhadap organisasi tempat dia bekerja sehingga bisa bekerja dengan baik dan output siswa yang dihasilkan bagus. Oleh karena itu komitmen guru terhadap organisasi adalah sebuah keharusan karena dengan komitmen yang tinggi terhadap organisasi guru dapat bekerja dengan sepenuh hati, loyalitas tinggi, setia, tidak mudah berpindah tempat kerja dan memberikan kemampuan terbaiknya.

Berdasarkan latar belakang di atas maka perumusan masalah dalam penelitian ini sebagai berikut : (1) Apakah terdapat hubungan antara kepemimpinan situasional kepala sekolah dengan komitmen guru terhadap organisasi?: (2) Apakah terdapat hubungan antara komunikasi interpersonal kepala sekolah dengan komitmen guru terhadap organisasi?; (3) Apakah terdapat hubungan antara kepemimpinan situasional kepala sekolah dan komunikasi interpersonal secara bersama sama dengan komitmen guru terhadap organisasi?

\section{Komitmen Terhadap Organisasi}

Komitmen menurut Colquit (2011: 69-78) adalah "keinginan individu untuk tetap menjadi anggota organisasi." Komitmen terhadap organisasi menjadi salah satu faktor penentu apakah ia ingin tetap menjadi anggota organisasi atau ia berupaya untuk keluar ( mencari perkejaan di organisasi lain). Senada dengan teori Colquit di atas, Spector (2008: 243-242) mengatakan bahwa "komitmen terhadap organisasi adalah sikap dan keterlibatan individu terhadap organisasi yang ditunjukkan dengan 1) penerimaan terhadap tujuan tujuan, 2) kesediaan untuk bekerja keras bagi organisasi, 3) keinginan untuk tetap bekerja dalam organisasi."

Sementara itu, Greenberg (2011: 231-236 ) menyatakan bahwa komitmen terhadap organisasi adalah "sejauh mana individu mengidentifikasikan diri dan ingin melibatkan diri dengan organisasi dan tidak ingin meninggalkannya." Faktor faktor yang mempengaruhinya adalah : (1) Komitmen kontinuan yaitu keinginnan individu untuk tetap bekerja pada organisasi baik karena kebutuhannya sendiri atau karena ia tidak menemukan tempat lain, (2) Komitmen afektif yaitu keinginan individu untuk tetap bekerja di organisasi karena ia menyenangi dan ingin melakukannya, (3) Komitmen normatif yaitu keinginan individu untuk tetap melanjutkan bekerja di organisasi karena ia merasa memiliki untuk tetap dalam organisasi.

Sementara itu Glinov (2010:112-113) menyatakan bahwa komitmen terhadap organisasi adalah "keterikatan emosi karyawan yang dapat diidentifikasikan dari keterlibatan dan loyalitas terhadap organisasi." Komitmen menurut Shane mempunyai tiga dimensi yaitu : komitmen kontinuan yaitu merasa sebagai bagian dari organisasi, komitmen normatif yaitu loyalitas terhdap organisasi dan komitmen afektif yaitu adanya keterlibatan dengan organisasi yang diikuti.

Berdasarkan teori teori yang dikemukakan para ahli di atas dapat disintesiskan bahwa komitmen terhadap organisasi adalah keterikatan seseorang yang mencerminkan identifikasi diri, keterlibatan, kesetiaan, penerimaan sepenuhnya pada nilai nilai organisasi serta adanya ikatan psikologis yang kuat terhadap organisasi dengan indikator indikator yang mempengaruhi : (1) dimensi komitmen normatif, dengan indikator: tanggung jawab pada organisasi, memiliki loyalitas tinggi pada organisasi, memiliki kewajiban terhadap organisasi, (2) dimensi komitmen afektif, dengan indikator : lingkungan kerja, kesetiaan, organisasi mempunyai arti yang besar. (3) dimensi komitmen kontinuitas, dengan indikator : kebutuhan 
terhadap organisasi karena gaji yang diterima, perasaan diakui, peluang kerja yang baik, aksesibililtas.

\section{Kepemimpinan Situasional}

Robbins (2012:494-495) mengemukakan kepemimpinan situaasional adalah "kepemimpinan yang fokus pada kesiapan pengikut". Menurut Stephen P. Robbins faktor faktor yang mempengaruhinya adalah : telling ( memberitahu), selling ( menjual), participating ( berpartisipasi), delegating ( mendelegasikan) serta tingkat kesiapan pengikut yang meliputi : kemampuan dan kemauan pengikut.

Definisi kepemimpinan situasional sebagaimana yang dikemukakan oleh Schermehorn et al., (2012:301) yaitu : "kepemimpinan yang fokus pada situasi tingkat kedewasaan dan kesiapan pengikut". Ada 4 faktor dimensi menurut Schermehorn et al, yaitu : a. Memberitahu artinya pimpinan memberikan arahan dengan jelas apa yang harus dilakukan, $b$. Menjual artinya pemimpin memberitahu namun ada komunikasi dua arah dengan bawahan, c. Partisipasi artinya pemimpin tidak banyak memerintah namun lebih banyak pola hubungan dan kerja sama tim serta, d. Mendelegasikan, pemimpin memberi tanggung jawab tidak banyak terlibat hanya mengawasi saja.

Slocum Jr (2011:304-306) menyatakan bahwa kepemimpinan situasional adalah "gaya kepemimpinan yang disesuaikan dengan level kesiapan bawahannya." Menurut Don Hellriegel (2011:304-306), ada beberapa faktor yang mempengaruhi dalam kepemimpinan situasional ini, yaitu : (1) gaya memberitahu yaitu gaya yang ditujukan kepada bawahan dengan kesiapan bekerja yang rendah, (2) gaya menjual yaitu gaya yang ditujukan kepada bawahan dengan kesiapan kerja yang sedang, (3) gaya partisipasi yaitu gaya yang diterapkan pada bawahan dengan tingkat kesiapan yang baik, (4) gaya mendelegasikan yaitu gaya yang ditujukan kepada bawahan dengan tingkat kesiapan kerja yang paling baik/tinggi.

Gibson (2012:323-324 ) mengemukakan tentang teori kepemimpinan situasional adalah "kepemimpinan yang membantu pimpinan mengerti kebiasaan bawahan dan situasi kondisi disekitarnya sebelum menerapkan model kepemimpinan yang akan digunakan." Faktor faktor yang mempengaruhi nya adalah : (1) mengerti karakter bawahan, (2) mencermati situasi yang sedang berlangsung sebelum menentukan pola kepemimpinan yang akan diambil.

Berdasarkan teori para ahli yang dipaparkan di atas dapat disintesiskan bahwa kepemimpinan situasional adalah perilaku pemimpin yang menyesuaikan dengan situasi dan kondisi bawahan yang berbeda satu dengan yang lainnya sementara indikator indikator yang mempengaruhinya adalah : (a) dimensi telling dengan indikator pemimpin memberikan arahan yang jelas dalam memberikan tugas, (b) dimensi selling dengan indikator : Pemimpin melakukan komunikasi dua arah, (c) dimensi participating dengan indikator : pemimpin memberikan tugas dan tanggung jawab pada bawahan, pemimpin mendukung bawahan dalam melakukan pekerjaannya dan (d) dimensi delegation dengan indikator yaitu : pemimpin memberi wewenang pada bawahan dalam bekerja.

\section{Komunikasi Interpersonal}

Foss (dalam Hidayat, 2012:41) mengatakan bahwa komunikasi interpersonal adalah "komunikasi antara individu individu dalam menyampaikan ide." Komunikasi interpersonal dapat berlangsung dengan efektif, apabila terdapat beberapa aspek yang harus diperhatikan oleh para pelaku komunikasi interpersonal tersebut adalah : a. Proses hubungan bersifat psikologis, b. Bersifat langsung, c. Pada proses penyampaian pesan , d. Disampaikan melalui verbal dan non verbal, e. Bersifat informal dan flexsibel. Sementara itu Gibson ( 2012:446448) mengatakan bahwa komunikasi interpersonal adalah "komunikasi yang berlangsung diantara dua individu dalam suasana tatap muka atau situasi kelompok." Jadi bisa dikatakan bahwa dalam komunikasi interpersonal ini faktor faktor yang terdapat di dalamnya adalah : 
(1) berlangsung secara tatap muka, (2) bersifat langsung bertemu dalam satu waktu, (3) adanya umpan balik dari sebuah pesan.

Gibson (2012:439) menyatakan bahwa komunikasi interpersonal adalah "komunikasi yang diikuti antara pribadi dalam tatap muka atau situasi kelompok." Faktor faktor yang mempegaruhi komunikasi interpersonal adalah : (1) adanya umpan balik, (2) interaksi tatap muka dan (3) adanya persepsi makna antar individu yang berkomunikasi. Komunikasi interpersonal dilakukan atas dasar sudah saling mengenal, percaya, menghormati, rasa memiliki dan rasa senang (Hidayat 2017)

Hardjana (dalam Suranto, 2011:3) menyatakan bahwa komunikasi interpersonal adalah "interaksi tatap muka antara dua atau beberapa orang dimana pengirim dapat menyampaikan pesan secara langsung dan penerima pesan dapat menerima dan menanggapi secara langsung pula." Sedangkan menurut Wood (2013:23) mengatakan bahwa komunikasi interpersonal adalah "proses transaksi yangs elektif, sistemis dan unik yang membuat kita merefleksikan dan mampu membangun pengetahuan bersama orang lain."

Dengan demikian berdasarkan pendapat para ahli tersebut di atas dapat disintesiskan bahwa komunikasi interpersonal adalah penyampaian pesan diantara dua orang atau lebih secara pribadi terdapat interaksi diantara mereka dan bersifat tatap muka dimana setiap peserta dapat menangkap rekasi orang lain secara langsung baik verbal maupun non verbal dengan indikator indikatornya yaitu 1) Tatap muka, 2) Bersifat langsung, 3) bersifat pribadi 4) Interaksi antara komunikan dan komunikator 5) Umpan balik

\section{METODE PENELITIAN}

Penelitian akan dilaksanakan di sekolah sekolah MTS Swasta di lingkungan kelompok kerja madrasah (KKM) MTsN Sagaranten kabupaten Sukabumi Jawa Barat yaitu di MTSS Bina Bangsa, MTSS Lingkungan Hidup, MTSS Tunas Harapan Bangsa, MTSS Miftahul Huda, MTSS Manbaul Ulum, MTSS Al Haq 1, MTSS Al Huda, MTSS Darul Asymawiyah, MTSS ciherang, MTSS Tarbiyatul Islamiyah, terhadap Guru Tetap Yayasan yang mengajar di MTS swasta tersebut. Penelitian akan dilaksanakan pada bulan maret sampai November 2017. Metode yang digunakan dalam penelitian ini adalah metode survai dengan teknik korelasi.

Populasi penelitian ini adalah para guru tetap yang bekerja pada MTS swasta yang terdapat di lingkungan KKM MTsN Sagaranten Kabupaten Sukabumi Provinsi Jawa Barat . Penentuan sample dengan menggunakan teknik proposional random sampling. Sesuai dengan perthitungan rumus Taro Yamane di atas, maka dari populasi sebanyak 150 orang diperoleh sample sebanyak 109 orang.

\section{HASIL PENELITIAN}

\section{Pengujian Persyaratan Analisis}

\section{Uji Normalitas}

Hasil perhitungan normalitas galat baku taksiran $\left(\mathrm{Y}-\hat{\mathrm{Y}}_{1}\right)$ didapatkan nilai $\mathrm{L}_{\mathrm{o} \text { maks }}=$ 0.083885 sedangkan $\mathrm{L}_{\text {tabel }}=0,08486(\mathrm{dk}=109$ dan $\alpha=0,05)$ dan $\mathrm{L}_{\text {tabel }}=0,09875(\mathrm{dk}=109$ dan $\alpha=0,01)$ Persyaratan normal adalah $\mathrm{L}_{\mathrm{o} \text { maks }}<\mathrm{L}_{\text {tabel, }}$, hal ini memperlihatkan bahwa galat baku taksiran $\left(\mathrm{Y}-\hat{\mathrm{Y}}_{1}\right)$ dari persamaan regresi $\hat{\mathrm{Y}}=86,456+0.30185 \mathrm{X}_{1}$ antara Kepemimpinan Situasional $\left(\mathrm{X}_{1}\right)$ dengan Komitmen Terhadap Organisasi (Y) berasal dari data yang berdistribusi normal.

Hasil perhitungan normalitas galat baku taksiran $\mathrm{Y}-\hat{\mathrm{Y}}_{2}$ didapatkan nilai $\mathrm{L}_{\mathrm{o}}$ maks $=$ 0,059263 sedangkan $\mathrm{L}_{\text {tabel }}=0,08486(\mathrm{dk}=109$ dan $\alpha=0,05)$ dan $\mathrm{L}_{\text {tabel }}=0,09875(\mathrm{dk}=109$ 
dan $\alpha=0,01)$. Persyaratan normal adalah $\mathrm{L}_{\mathrm{o} \text { maks }}<\mathrm{L}_{\text {tabel,. }}$ Maka hal ini menunjukkan bahwa galat baku taksiran $\left(\mathrm{Y}-\hat{\mathrm{Y}}_{1}\right)$ dari persamaan regresi yaitu : $\hat{\mathrm{Y}}=96,263+0,2545 \mathrm{X}_{2}$. antara Komunikasi Interpersonal $\left(\mathrm{X}_{2}\right)$ dengan Komitmen Terhadap Organisasi $(\mathrm{Y})$ berasal dari data yang berdistribusi normal.

\section{Uji Homogenitas}

Berdasarkan hasil perhitungan diperoleh nilai $\chi_{\text {hitung }}^{2}=-45,54$ sedangkan dari tabel Chi Kuadrat diperoleh $\chi_{\text {tabel }}^{2}=72,15$ dengan $\mathrm{dk}=54$ dan taraf signifikan $\alpha=0,05$. Persyaratan data homogen adalah $\chi_{\text {hitung }}^{2}<\chi_{\text {tabel, }}^{2}$ maka $\chi_{\text {hitung }}^{2}-45,54<\chi_{\text {tabel }}^{2} 72,15$ dengan demikian varians kelompok data Komitmen Terhadap Organisasi (Y) berdasarkan data kepemimpinan situasional $\left(\mathrm{X}_{1}\right)$ berasal dari populasi yang homogen.

Berdasarkan hasil perhitungan diperoleh nilai $\chi_{\text {hitung }}^{2}=15,47$ sedangkan $\chi_{\text {tabel }}^{2}=88,25$ $(\mathrm{dk}=61$ dan $\alpha=0,05)$. Persyaratan data homogen adalah $\chi_{\text {hitung }}^{2}<\chi_{\text {tabel }}^{2}$, maka $15,47 \chi_{\text {hitung }}^{2}$ $<\chi_{\text {tabel }}^{2} 88,25$ dengan demikian varians kelompok data komitmen terhadap organisasi (Y) berdasarkan data komunikasi interpersonal $\left(\mathrm{X}_{2}\right)$ berasal dari populasi yang homogen.

\section{Pengujian Hipotesis}

\section{Hubungan antara Kepemimpinan situasional $\left(X_{1}\right)$ dengan Komitmen Terhadap Organisasi(Y)}

Berdasarkan hasil analisis regresi sederhana, diperoleh konstanta regresi atau $a$ (intercept) sebesar 86,456 dan koefisien regresi atau $b$ (slope) sebesar 0,30185. Sehingga hubungan fungsional antara $\mathrm{X}_{1}$ dengan $\mathrm{Y}$, dapat disajikan dalam bentuk persdamaan regresi sebagai berikut : $\hat{Y}=86,456+0,30185 \mathrm{X}_{1}$. Dalam menguji hipotesis yang menyatakan bahwa terdapat hubungan positif antara kepemimpinan situasional $\left(\mathrm{X}_{1}\right)$ dengan komitmen terhadap organisasi (Y) maka diperlukan uji signifikansi dan linieritas terhadap persamaan regresi $\hat{\mathrm{Y}}=$ $86,456+0,3018 \mathrm{X}_{1}$ dengan menggunakan uji $\mathrm{F}$.

Sedangkan dalam menguji persamaan regresi tersebut apakah linier atau tidak, perlu dilakukan uji linieritas dengan uji F. Syarat kelinieran persamaan regresi apabila $F_{\text {hitung }}<$ $\mathrm{F}_{\text {tabel. }}$. Berdasarkan hasil perhitungan diperoleh $\mathrm{F}_{\text {hitung }}=0,4855$ sedangkan $\mathrm{F}_{\text {tabel }}=1,57(\mathrm{dk}$ pembilang $=57$, dk penyebut $=50$ dan $\alpha=0.05$ ) dengan demikian persamaan regresi $\hat{\mathrm{Y}}=$ $86,456+0,30185 \mathrm{X}_{1}$ adalah linier sehingga rumus korelasi Product Moment Pearson dapat digunakan. Nilai koefesiensi determinasi antara kepemimpinan situasional $\left(\mathrm{X}_{1}\right)$ dengan komitmen terhadap organisasi (Y) adalah $\mathrm{r}_{\mathrm{y} 1}^{2}=0,1875$ hal ini berarti bahwa $18,75 \%$ varian komitmen terhadap organisasi dapat dijelaskan oleh variabel kepemimpinan situasional.

\section{Hubungan antara Komunikasi Interpersonal $\left(X_{2}\right)$ dengan Komitmen Terhadap Organisasi (Y)}

Berdasarkan hasil analisis regresi sederhana, diperoleh konstanta regresi atau $a$ (intercept) sebesar 96,263 dan koefisien regresi atau $b$ (slope) sebesar 0.2545. Sehingga Hubungan fungsional antara $\mathrm{X}_{2}$ dengan $\mathrm{Y}$, dapat disajikan dalam bentuk persamaan regresi sebagai berikut : $\hat{Y}=96,263+0,2545 X_{2}$. Untuk menguji hipotesis bahwa terdapat hubungan positif antara komunikasi interpersonal $\left(\mathrm{X}_{2}\right)$ dengan Komitmen Terhadap Organisasi (Y) maka diperlukan uji signifikansi dan linieritas terhadap persamaan regresi dengan menggunakan uji F. Persyaratan hipotesis teruji apabila $F_{\text {hitung }}>F_{\text {tabel }}$ (untuk uji signifikansi regresi).

Syarat kelinieran persamaan regresi apabila $F_{\text {hitung }}<\mathrm{F}_{\text {tabel. }}$ Berdasarkan hasil perhitungan diperoleh $F_{\text {hitung }}=1,1793$ sedangkan $F_{\text {tabel }}=1,57(\mathrm{dk}$ pembilang $=39$, dk penyebut $=68$ dan $\alpha=0,05)$ dengan demikian persamaan regresi $\hat{Y}=96,263+0,2545 X_{2}$ adalah linier sehingga rumus korelasi Product Moment Pearson dapat digunakan. 
Berdasarkan hasil perhitungan diperoleh $\mathbf{t}_{\text {hitung }}=3,5365$ sedangkan nilai $t_{\text {tabel }}=1,95$ $(\mathrm{dk}=107$ dan $\alpha=0,05)$ dan $\mathrm{t}_{\text {tabel }}=2,62(\mathrm{dk}=107$ dan $\alpha=0,01)$. Hal ini berarti bahwa koefesien korelasi antara komunikasi interpersonal $\left(\mathrm{X}_{2}\right)$ dengan komitmen terhadap organisasi (Y) adalah signifikan.

\section{Hubungan antara Kepemimpinan Situasional $\left(X_{1}\right)$ dan Komunikasi Interpersonal} $\left(\mathbf{X}_{2}\right)$ secara bersama-sama dengan Komitmen Terhadap Organisasi ( $Y$ )

Hubungan fungsional antara $\mathrm{X}_{1}$ dan $\mathrm{X}_{2}$ dengan $\mathrm{Y}$, dapat disajikan dalam bentuk persamaan regresi sebagai berikut : $\hat{Y}=76.31+0.22 \mathrm{X}_{1}+0.17 \mathrm{X}_{2}$. Untuk menguji hipotesis bahwa terdapat hubungan positif antara Kepemimpinan Situasional $\left(\mathrm{X}_{1}\right)$ dan Komunikasi Interpersonal $\left(\mathrm{X}_{2}\right)$ secara bersama-sama dengan Komitmen Terhadap Organisasi (Y) maka diperlukan uji signifikansi dan linieritas terhadap persamaan regresi ganda dengan menggunakan uji $\mathrm{F}$.

Kekuatan hubungan antara variabel Kepemimpinan Situasional $\left(\mathrm{X}_{1}\right)$ dan Komunikasi Interpersonal $\left(\mathrm{X}_{2}\right)$ secara bersama-sama dengan Komitmen Terhadap Organisasi (Y) adalah $\mathbf{r}_{\mathrm{y} .12}=0,3965$, menunjukkan kekuatan hubungan yang sedang. Untuk menguji hipotesis bahwa terdapat hubungan positif antara variabel $\mathrm{X}_{1}$ dan $\mathrm{X}_{2}$ dengan variabel $\mathrm{Y}$ diperlukan uji signifikansi yaitu dengan uji t. Kriteria pengujian signifikansi koefesien korelasi multipel adalah jika $F_{\text {hitung }}>F_{\text {tabel }}$ maka koefesien korelasi ganda berdasarkan hasil perhitungan adalah signifikan.

Berdasarkan hasil pengujian hipotesis di atas dapat disimpulkan bahwa hipotesis yang menyatakan bahwa hubungan positif antara variabel Kepemimpinan Situasional $\left(\mathrm{X}_{1}\right) \mathrm{dn}$ Komunikasi Interpersonal $\left(\mathrm{X}_{2}\right)$ secara bersama-sama dengan Komitmen Terhadap Organisasi (Y) dapat diterima, artinya makin baik kepemimpinan situasional dan makin baik komunikasi interpersonal secara bersama-sama maka semakin tinggi komitmen terhadap organisasi.

\section{Uji Korelasi Parsial}

Berdasarkan hasil perhitungan diperoleh nilai $\mathbf{r}_{\mathrm{y} 1.2}=0,2472$, hal ini menunjukkan hubungan parsial yang sedang antara $X_{1}$ dengan $Y$. Nilai $\mathbf{t}_{\text {hitung }}=2,2658$ sedangkan $\mathbf{t}_{\text {tabel }}=$ $1.98(\mathrm{dk}=107$ dan $\alpha=0,05)$ dan $\mathbf{t}_{\text {tabel }}=2,62(\mathrm{dk}=107$ dan $\alpha=0,01)$. Syarat signifikansi $\mathbf{t}_{\text {hitung }}>\mathbf{t}_{\text {tabel }}$. Koefisien determinasi $\left(\mathrm{r}_{\mathrm{y} 1.2}\right)^{2}=0,0610$ sehingga dapat disimpulkan bahwa variabel komunikasi interpersonal dikontrol, maka variabel kepemimpinan situasional berkontribusi terhadap Kepemimpinan situasional sebesar 0,61\%. Selanjutnya berdasarkan hasil perhitungan diperoleh nilai $\mathbf{r}_{\mathrm{y} 2.1}=0,2175$, hal ini menunjukkan hubungan parsial yang sedang antara $\mathrm{X}_{2}$ dengan Y. Nilai $\mathbf{t}_{\text {hitung }}=2,1990$ sedangkan $\mathbf{t}_{\text {tabel }}=1.98(\mathrm{dk}=107$ dan $\alpha=$ $0,05)$ dan $\mathbf{t}_{\text {tabel }}=2,62(\mathrm{dk}=107$ dan $\alpha=0,01)$. Syarat signifikansi $\mathbf{t}_{\text {hitung }}>\mathbf{t}_{\text {tabel. }}$. Koefisien determinasi $\left(\mathrm{r}_{\mathrm{y} 1.2}\right)^{2}=0,0473$, sehingga dapat disimpulkan bahwa variabel kepemimpinan situasional dikontrol, maka kontribusi variabel komunikasi interpersonal terhadap variabel komitmen terhadap organisasi sebesar $0,47 \%$

\section{PEMBAHASAN}

\section{Hubungan Variabel Kepemimpinan Situasional $\left(X_{1}\right)$ dengan Variabel Komitmen terhadap Organisasi (Y)}

Hasil penelitian membuktikan bahwa terdapat hubungan positif dan signifikan antara kepemimpinan situasional dengan komitmen terhadap organisasi. Kekuatan hubungan antara kepemimpinan situasional dengan komitmen terhadap organisasi dapat dilihat dari nilai koefesien korelasi (ry1) sebesar 0,4330, menunjukkan hubungan yang sedang antara kedua variabel tersebut. Nilai koefesien determinasi (ry1)2 sebesar 0,1875, hal ini berarti varian komitmen terhadap organisasi dapat dijelaskan oleh varian kepemimpinan situasional sebesar 
18,75\%. Bentuk hubungan antara kepemimpinan situasional dengan komitmen terhadap organisasi, (X1) dengan (Y) ditunjukkan oleh persamaan regresi $\hat{Y}=86,456+0.30185 X 1$, dimana secara kuantitatif dapat dikatakan bahwa setiap penambahan 1 unit kepemimpinan situasional akan meningkatkan komitmen terhadap organisasi 0,030185 unit.

Hasil penelitian tersebut sejalan dengan pendapat Spector ( 2008:243-242) yang mengatakan bahwa komitmen terhadap organisasi merupakan sikap dan keterlibatan individu terhadap organisasi yang ditunjukkan dengan penerimaan terhadap tujuan tujuan, kesediaan untuk bekerja keras bagi organisasi, keinginan untuk tetap bekerja dalam organisasi. Faktor faktor yang mempengaruhi komitmen terhadap organisasi ini menurut Spector adalah :

a) Komitmen afektif yang dipengaruhi oleh kondisi pekerjaan yaitu job condition atau kondisi kondisi yang menarik dan menyenangkan pada jabatan tersebut dan meet expectation yaitu pengalaman pengalaman berkesan selama bekerja

b) Komitmen kontinuan yang dipegaruhi oleh benefits accrued yaitu gaji, fasilitas dll yang tinggi dan sukar diperoleh di organisasi lain dan job available yaitu sukar berpindah pekerjaan ke organisasi yang lain

c) Komitmen normatif yaitu komitmen yang tumbuh dari dalam diri individu karena adanya nilai nilai dalam diri individu seperti kesetiaan, kesadaran dan felt obligations misalnya kewajiban atau norma norma yang harus ditaati.

Kepemimpinan situasional menurut Robbins (2012:494-495) merupakan kepemimpinan yang fokus pada kesiapan pengikut . Menurut Robbins faktor faktor yang mempengaruhinya adalah : telling ( memberitahu), selling ( menjual), participating ( berpartisipasi), delegating ( mendelegasikan) serta tingkat kesiapan pengikut yang meliputi : kemampuan dan kemauan pengikut.

Selanjutnya menurut Schermehorn (2012:301) yang dimaksud dengan kepemimpinan yang fokus yaitu : Kepemimpinan yang fokus pada situasi tingkat kedewasaan dan kesiapan pengikut dengan ciri: Memberitahu artinya pimpinan memberikan arahan dengan jelas apa yang harus dilakukan, menjual artinya pemimpin memberitahu namun ada komunikasi dua arah dengan bawahan, partisipasi artinya pemimpin tidak banyak memerintah namun lebih banyak pola hubungan dan kerja sama tim serta mendelegasikan, pemimpin memberi tanggung jawab tidak banyak terlibat hanya mengawasi saja.

Dengan demikian, untuk meningkatkan komitmen terhadap organisasi dapat dilakukan dengan meningkatkan kepemimpinan situasional. Semakin kondusif kepemimpinan situasional dimana para guru bekerja maka akan semakin tinggi komitmen terhadap organisasi.

\section{Hubungan Variabel Komunikasi Interpersonal $\left(\mathbf{X}_{2}\right)$ Dengan Variabel Komitmen Terhadap Organisasi (Y)}

Hasil penelitian membuktikan bahwa terdapat hubungan positif dan signifikan antara komunikasi interpersonal dengan komitmen terhadap organisasi. Kekuatan hubungan antara komunikasi interpersonal dengan komitmen terhadap organisasi dapat dilihat dari nilai koefesien korelasi (ry2) sebesar 0,3235, menunjukkan hubungan yang sedang antara kedua variabel tersebut. Nilai koefesien determinasi (ry2)2 sebesar 0,1047, hal ini berarti varian komitmen terhadap organisasi dapat dijelaskan oleh varian komunikasi interpersonal sebesar 10,47\%. Bentuk hubungan antara komunikasi interpersonal (X2) dengan komitmen terhadap organisasi (Y) ditunjukkan oleh persamaan regresi $\hat{Y}=96,263+0,2545 \mathrm{X} 2$, dimana secara kuantitatif dapat dikatakan bahwa setiap penambahan 1 unit komunikasi interpersonal akan meningkatkan komitmen terhadap organisasi 0,2545 unit.

Hasil penelitian tersebut sejalan dengan pendapat ahli yang mengatakan bahwa menurut George (2012: 89) komitmen terhadap organisasi merupakan perasaan dan kepercayaan 
orang yang memiliki organisasi secara keseluruhan. Dalam hal ini, menurut Jennifer and Garreth komitmen terhadap organisasi dipengaruhi oleh dua hal, yaitu :

a) Komitmen afektif, yaitu komitmen yang memperlihatkan rasa senang staff yang telah menjadi bagian dari organisasi. Turut terlibat dalam berbagai kegiatan sebagai bentuk rasa tanggung jawab terhadap organisasi yang diikuti

b) Komitmen kontinuan yaitu komitmen yang bisa membuat staf merasa dirinya diakui ketika ikut berperan dalam kegiatan yang bisa membuat organisasi maju dan merasa tidak berharga ketika staf tersebut tidak lagi bersama di dalam organisasi.

Shane (2010:112-113) mengungkapkan bahwa komitmen terhadap organisasi adalah keterikatan emosi karyawan yang dapat diidentifikasikan dari keterlibatan dan loyalitas terhadap organisasi. Komitmen menurut Shane ini mempunyai tiga dimensi yaitu : kontinuan komitmen yaitu merasa sebagai bagian dari organisasi, normative komitmen yaitu loyalitas terhdap organisasi dan komitmen afektif yaitu adanya keterlibatan dengan organisasi yang diikuti.

Foss, (dalam Hidayat, 2012:41) mengatakan bahwa komunikasi interpersonal adalah komunikasi antara individu individu dalam menyampaikan ide. komunikasi interpersonal dapat berlangsung dengan efektif, apabila terdapat beberapa aspek yang harus diperhatikan oleh para pelaku komunikasi interpersonal tersebut adalah : Proses hubungan bersifat psikologis, bersifat langsung, ada proses penyampaian pesan, disampaikan melalui verbal dan non verbal, bersifat informal dan flexsibel.

Selanjutnya, komunikasi interpersonal menurut Thoha (2009:190-191) merupakan proses penyampaian berita yang dilakukan seseorang dan diterimanya berita tersebut oleh orang lain atau sekelompok kecil orang sebagai akibat dari umpan balik yang segera. Dengan faktor faktor yang mempengaruhinya, yaitu : ada keterbukaan, empati, dukungan dan ada umpan balik. Dapat dikatakan bahwa dalam komunikasi interpersonal terdapat adanya keterbukaan, adanya empati, adanya dukungan kedua belah fihak dan terdapat umpan balik.

Dengan demikian, untuk meningkatkan komitmen terhadap organisasi dapat dilakukan dengan meningkatkan komunikasi interpersonal. Semakin tinggi komunikasi interpersoanal akan semakin tinggi komitmen terhadap organisasi.

\section{Hubungan Antara Kepemimpinan Situasional $\left(\mathbf{X}_{1}\right)$ Dan Komunikasi Interpersonal $\left(\mathbf{X}_{2}\right)$ Secara Bersama Sama Dengan Komitmen Terhadap Organisasi (Y)}

Hasil penelitian membuktikan bahwa terdapat hubungan positif dan signifikan antara kepemimpinan situasional dan komunikasi interpersonal dengan komitmen terhadap organisasi. Kekuatan hubungan antara kepemimpinan situasional dan komunikasi interpersonal dengan komitmen terhadap organisasi dapat dilihat dari nilai koefesien korelasi (ry.12) sebesar 0,3965, menunjukkan hubungan yang sedang antara variabel bebas dengan variabel terikatnya. Nilai koefesien determinasi (ry2)2 sebesar 0,1572, hal ini berarti varian komitmen terhadap organisasi dapat dijelaskan oleh varian kepemimpinan situasional dan komunikasi interpersonal secara bersama-sama sebesar 15,72\%. Bentuk hubungan antara kepemimpinan situasional (X1) dan komunikasi interpersonal (X2) dengan komitmen terhadap organisasi $(\mathrm{Y})$ ditunjukkan oleh persamaan regresi $\hat{\mathrm{Y}}=76.31+0.22 \mathrm{X} 1+0.17 \mathrm{X} 2$, dimana secara kuantitatif dapat dikatakan bahwa setiap penambahan 1 unit kepemimpinan situasional dan 1 unit komunikasi interpersonal akan meningkatkan komitmen terhadap organisasi $0,37(0,22+0,017)$ unit. Artinya, semakin tinggi skor kepemimpinan situasional dan skor komunikasi interpersonal akan semakin tinggi pula skor komitmen terhadap organisasi.

Hal ini sejalan dengan hasil penelitian yang dilakukan oleh Tain Fung Wu et all., 2006. Asian Journal of Management and Humanity Sciences, volume 1 no 3:434-452 yang berjudul 
A study of the relationship between manager's leadership style and organizatioal commitment in Taiwan's International tourist hotels menyimpulkan bahwa dari hasil penelitiannya Kepemimpinan Situasional $\left(X_{1}\right)$ selling berpengaruh secara signifikan terhadap Komitmen terhadap organisasi (Y) dengan nilai koefisien korelasi=0,53 nilai signfikan $(\alpha=0,01)$, Kepemimpinan Situasional $\left(\mathrm{X}_{1}\right)$ telling berpengaruh signifikan terhadap komitmen terhadap organisasi $(\mathrm{Y})$ dengan nilai koefisien korelasi $=0,093$ nilai signifikan $(\alpha=0,01)$, Kepemimpinan Situasional $\left(\mathrm{X}_{1}\right)$ participating berpengaruh signifikan terhadap komitmen terhadap organisasi $(\mathrm{Y})$ dengan nilai koefisien korelasi $=0,50$ nilai signifikan $(\alpha=0,01)$, Kepemimpinan Situasional $\left(X_{1}\right)$ delegating berengaruh signifikan terhadap komitmen terhadap organisasi $(\mathrm{Y})$ dengan nilai koefisien korelasi $=0,51$ nilai signifikan $(\alpha=0,01)$

Selanjutnya, Tiur Asi Siburian. 2013 International Journal of Humanities and Social Science.volume 3 no.12:247-264 yang berjudul The effect of interpersonal communication, organizational culture, job satisfaction and achievement motivation to organizational commitment of state high school teacher in the district Humbang Hasundutan, North Sumatera Indonesia menyimpulkan bahwa dari hasil penelitiannya khusus untuk variabel yang berkaitan diperoleh hasil bahwa Komunikasi interpersonal $\left(\mathrm{X}_{2}\right)$ berpengaruh secara signifikan terhadap Komitmen terhadap organisasi (Y) dengan nilai koefiien korelasi 0,64, nilai signifikan $\alpha 0,05$.

Merujuk pada beberapa hasil uji korelasi parsial antara kepemimpinan situasional dengan komitmen terhadap organisasi dimana nilai koefesien adalah sebesar ry1.2 $=0,2472$, menunjukkan bahwa hubungan antara kepemimpinan situasional dengan komitmen terhadap organisasi tetap signifikan meskipun dikontrol oleh Komunikasi interpersonal, atau dengan kata lain variabel Komunikasi interpersonal tidak mempengaruhi hubungan antara kepemimpinan situasional dengan komitmen terhadap organisasi.. Demikian pula dengan, hasil uji korelasi parsial antara Komunikasi interpersonal dengan Komitmen terhadap organisasi dimana nilai koefesien adalah sebesar ry2.1 $=0,2175$, menunjukkan bahwa hubungan antara kepemimpinan situasional dengan komitmen terhadap organisasi tetap signifikan meskipun dikontrol kepemimpinan situasional, atau dengan kata lain variabel kepemimpinan situasional tidak mempengaruhi hubungan antara Komunikasi interpersonal dengan Komitmen terhadap organisasi

\section{SIMPULAN}

Berdasarkan temuan penelitian di atas dapat disimpulkan bahwa kepemimpinan situasional dan komunikasi interpersonal memiliki peran dalam meningkatkan komitmen guru terhadap organisasi. Ini terbukti dari hasil penelitian ini bahwa kepemimpinan situasional memiliki kontribusi terhadap komitmen guru sebesar 18,75\%; komunikasi interpersonal memiliki kontribusi terhadap komitmen guru sebesar 10,47\%; dan kontribusi kepemimpinan situasional dan komunikasi interpersonal secara bersama sama terhadap komitmen guru sebesar $15,72 \%$.

\section{DAFTAR PUSTAKA}

Colquitt, Jason A. 2011.Organizational Behavior. New York: McGraw-Hill

Dasrun Hidayat, 2012. Komunikasi antar pribadi dan medianya, Yogyakarta : Graha Ilmu

Deddy Mulyana. 2012, Ilmu Komunikasi Suatu Pengantar . Bandung : Remadja 
Greenberg,J. R.A. Baron. 2011. Behavior in Organizations. Upper Saddle River, NJ: Pearson Education

Hidayat, Rais. 2017. Peningkatan Aktivitas Komunikasi Interpersonal Dalam Organisasi Melalui. Kelola, Jurnal Manajemen Pendidikan 4(2): 161-70.

Hellriegel, Don . 2011. Organizational Behavior. Mason: Cengage Learning.

Ivancevich et all., 2008. Organizational behavior and management, New York: Mc.Graw Hill

Jaros,Stephen.2007. Model of Organizational Commitment: Measurement Issues, The

Robbins, Stephen P. Timothy A. Judge. 2013. Organizatinal Behavior, 15th ed. USA : Prentice Hall

Schermehorn, Jhon R et all. 2012. Organization Behavior; twelfth edition. New Jersey : Jhon Willey \&Sons.

Spector, P.E.. 2008. Industrial and Organizational Psychology. New York: John Wiley \& Sons.

Robbins, Stephen P dan Mary Coulter. 2012. Management global edition, eleventh edition. New York: Jhon Willey.

TF.Wui.et.al . 2006. Study of the Relationship between Manager's Leadership Style and Organizational Commitment in Taiwan's International Tourist Hotels. Asian Journal of Management and Humanity Sciences, Volume. 1, No. 3 : 434-452

Tiur Asi Siburian. 2013. The Effect of Interpersonal Communication, Organizational Culture, Job Satisfaction, and Achievement Motivation to Organizational Commitment of State High School Teacher in the District Humbang Hasundutan, North Sumatera, Indonesia. International Journal of Humanities and Social Sciences. Volume 3 no 12.: 247-264

Wood, Julia T. 201. Komunikasi Interpersonal : Interaksi keseharian : Salemba Humanika : Jakarta

Wood,Jack.2013, Organisational Behaviour : Core concepts adn applications : Third Australasan Edition,Milton : Melbourne

Schermehorn, Jhon R et all. 2012. Organization Behavior; twelfth edition. New Jersey : Jhon Willey \&Sons.

Slocum. 2011. Organizational behavior, thirteenth edition, Mason,: Cengage Learning 